\title{
The evangelical church of Zaire and the female ordained ministry 1
}

\author{
M M Mulemfo \\ Department of Missiology (Sec B) \\ University of Pretoria
}

\begin{abstract}
African culture(s) had assigned inferior roles to women in society. The first Christian missionaries did very little to liberate women from this cultural enslavement. The missionaries's understanding of the leadership roles of women was not very different from that of African culture and its societal organisation. Many churches in Africa had kept to this cultural conservatism and also adopted the missionary theology. However, there are some Christians who accept women into the pastoral ministry, while others consider this move as blasphemous and unbiblical. The role of the church in this conflictual issue is to elaborate a new biblical hermeneutic which would help the church to create a conducive environment where men and women would understand their humanity on an equal basis and participate in God's salvific mission for the world.
\end{abstract}

\section{THE MANIANGA CULTURE AND WOMEN}

Women in the African context, and particularly among the Manianga are not considered objects but are human beings. However, one has to bear in mind that the respect given to the humanity of women is subjected to some conditions. The society believes that women are inferiors to men and that the primary goal on the existence of women is to bear children for their husband and relatives, and their clan. Women are the ones who should handle all the family affairs, that is cooking food, the education of children on all levels of life: cultural, spiritual and social. They have the integral role of taking care of children (Knapen 1962:61). Men are also involved, but the full responsibility is in the hands of women. This is understandable, because the children belong to the clan of the women.

* Most of the ideas developed in this article are from the author's $\mathrm{Ph} \mathrm{D}$ thesis, 'Palaver as a dimension of communal solidarity in Zaire: A missiological study on transgression and reconciliation', pp 164178. This dissertation, with Prof Dr J J Kritzinger as promoter, was submitted and accepted in 1995 by the Faculty of Theology (Section B), University of Pretoria. 
Being that the African society is male orientated, one observes some cultural pressures on women. It is quite difficult to generalise the attitudes which African men have about women, but without doubt all Bantu speaking Africans have the same assumptions of women. The manhood orientation of the society has been accepted by women as a normal order. I agree with Omoyajowo (1988:77) when he says that: 'Generally speaking, the superiority of men over women has always been taken for granted. Women themselves seem to have internalised this image of female inferiority and have somehow taken male domination as the natural order of things'.

The superiority of men allows them to marry many women and also divorce them. This is a sign of power. Women have certain duties which they have to fulfil in the house and in society.

From a certain age adults educate children according to their views of what the children should do and be. This empirical education is done according to the gender of the children. All girls are educated by women in the kitchen and are taught to be good mothers. However, boys are educated in a separate place which is called 'boko''. Traditionally, the 'boko' is considered as a meeting place and an educational institution. Although the 'boko' was and still is a very important place, where spiritual, moral and social matters are dealt with, the fact that no participation of women is accepted in taking part in discussions and decisions, make it one of the factors which entrenched the alleged inferiority of women in the mind of boys. Women are only invited to the 'boko' during the big gathering where everybody in the clan or village are supposed to attend. Even then their participation is limited during the discussions and are not seated on the same side as men.

\section{THE SWEDISH MISSIONARIES AND WOMEN}

During the missionary era, little was done by the Swedish Christian missionaries to liberate women from the Manianga cultural pressures. 'The teaching of the missionaries certainly did very little to affirm an equal citizenship of women and men in the Kingdom of God' (Tisani 1989:81). As the Swedish missionaries failed to address the traditional issues which affected women (such as the price of the dowry and different types of social injustices), they concentrated themselves in developing women's skills. The Swedish missionaries built professional schools where girls learnt how to care for their homes once married (Palmaer \& Stenström 1961:83-84). In these schools the girls also learned how to read and write. Later on this helped women to devote themselves to the reading of the Bible in the community and stimulated them to go to high schools (Stenström 1990:12). Despite of their education, women were not and still are not truly liberated from men's superiority. 
In the traditional setting, women were never promoted to the leadership position. This attitude was not strange in the mind of the Swedish missionaries. For from the start of their missionary work among the Manianga (1881) up to the time that the 'Local Church' 'got its independence (1961), the Swedish missionaries never allowed women to the leadership position in the Church such as to the female ordained ministry. This could be seen in the training process of the natives to the pastoral ministry. The first theological students who went to the Bible school in Kimpese (1939) were all men (Palmaer \& Stenström 1961:95). From the above, one would affirm that the compatibility of the missionary approach with the African culture encouraged men to further believe that women were inferior to them.

\section{THE LOCAL CHURCH AND WOMEN}

After its independence, the local church also adopted the mission theology and attitude of the Swedish missionaries towards the issue of the female ordained ministry. Women could not preach in the church but they had certain freedom to exercise in some services. Kukangisa (1988:122) underlines that:

Women went to church every Sunday and partook of the Holy Communion just like men. During the service, they had the right to pray publicly and sing in the choir. The deaconesses were allowed to take up the collection and to hand out the gifts of the Holy Communion. In spite of this comparative freedom, there were a number of tasks to which women had no access. They were not allowed to lead a service for instance, nor to preach. In this matter, men indiscriminately referred to the words of the apostle Paul, 'Women should remain silent in the church' (1 Cor 14:34).

However, as time went on, some people in the church came to change their theology and accept that women should be ordained and exercise all functions that a male pastor could do in the church. Kukangisa (1988:123) continues that: 'Since 1972, there are women pastors within the Evangelical Church of Zaire. They have all the rights of a pastor, they practise counselling, preach, officiate, celebrate the Holy Communion, officiate at marriages, et cetera'. Indeed, the presence of women in the ordained ministry is an exciting thing to some church members, but to others it is still a blasphemous act. The latter group feels that women are not meant for leadership positions in the church or even in society (Luzolo, T, November 1993, personal interview). This mentality is rooted among these people for two reasons: (1) the cultural conservatism which 
emphasises the superiority of men is still a fundamental factor in their life; (2) the deep seated teaching on the inferiority of women by the so called 'Bangunza' - prophets - who emerged from the renewal of Kimbangu 4 . In terms of the Christian faith, the event of the Kimbanguist revival has left some tensions among the Manianga Christians. People fight about the gifts of the Holy Spirit and their use in the church.

The Local Church is facing a real crisis in this matter. A charismatic movement exists within the church which is called 'Nenga' - to be away or in private. The members of this movement call themselves 'Nsadidila' - remnants - of the previous prophets. Most of these members belong to the Local Church and some exercise different functions. This movement has developed a sectarian type of theology which encourages its members to see themselves as the most pure and holy among all other Christians. The members of this movement participate as do all other local church members in the Sunday services. After the Sunday service is over, these members are supposed to gather again later in the afternoon at their own place (in a house or temple). During that time, the members are asked to wear white clothes (these clothes are unique to themselves) which symbolise purity, holiness and sanctification from the blood of Jesus Christ (Massamba, K, November 1993 personal interview).

The leaders of this movement have also developed a certain Christology that considers Jesus Christ as the founder of 'Nenga'. They say that throughout His ministry, Jesus Christ went away, alone, or with His disciples either to explain to them the meaning of the miracles or to pray (Mt 14:23; 26:36; Lk 5:16; 6:12; 9:18,29; 11:1; Jn 17; etc). Therefore as Christians, our duty is to do what Jesus Christ did so that we may be called His disciples (Massamba, K, November 1993, personal interview).

More emphasis is put on the role of women in the Church of Christ. According to their theology, a woman who is a true Christian should cover her hair (1 Cor 11;5-6); is not allowed to preach in the church (1 Cor 14:33-34); must be submissive (Eph 5:22; Tm 2:11-15); she is impure during her menstrual period or at the time of giving birth (Lv 12:1-6; 15:19-29). These biblical passages are considered as background to the whole theological teaching on the issue regarding women (Bikuta, T, December 1993, personal interview).

This situation is a real handicap to the church in creating a climate from which men and women could live together on an equal basis. The need for new theological and missiological approaches, I think, would help Christians understand that God is a God of relationships and that the implications of His life in the lives of human beings would also provide new patterns in their relationships. 


\section{THE BIBLE AND WOMEN}

My intention in this point is to highlight some of the texts in the Bible (Old \& NewTestaments) that are often read and used either to justify the subordination of women to men or the prohibition of women to the ordained ministry in the Church. I would also like to draw the attention of readers that my approaches in studying these texts are interpretative and missiological rather than exegetical.

\subsection{The Book of Genesis and the stories of creation}

In the Old Testament, the book of Genesis presents us the two stories of creation and the manner in which God created human beings. However, it seems that the styles in which the stories have been recorded differ from one another. This may be an indication that the two stories represent two independent sources or have been written in different places. Maher (1982:13) argues that: 'parallel passages where the same story is told two or three times - seem to indicate that different versions of the same story have been recorded in different sources, and perhaps in different localities'. As far as the story of creation in Genesis 1:27 is concerned, the style of the author seems not to help us to know how God created human beings. The text says 'So God created man in his own image, in the image of God he created him; male and female he created them' (NIV). This uncertainty could lead many people to interpret the text literally, in other words, man was created first and he was bisexual. Following this interpretation, Cassuto (1972:57-58) disagrees that:

Male and female He created them. According to the rabbinic interpretation ... man was created with two faces, that is, a hermaphrodite. This, too, is how many commentators of our day, basing their view on similar legends that were current in the ancient world understand the passage. But this is not the true sense of the verse, for it distinctly states: He created THEM - in plural.

Hamilton (1990:138) affirms that: 'Rather the verse affirms that God created in his image a male adam and a female adam. Both share the image of God'. In the same way Clark (1980:14) suggests that:

The progression would then be something like this: God created the human race in his own image so that it could have domination over living things. Moreover, he created the human race male and female so that the race could increase and fill the earth. 
The above text still does not give us more clarity on the whole process of creation. In Genesis 2:18ff, one reads inspite his image of God, 'The Lord said, It is not good for man to be alone .... Then the Lord God made a woman from the rib he had taken out of man, and he brought her to the man ....' (NIV). It seems that this second text is clearer than the first as it explains especially how the woman was created. But still there may be some dangers in the interpretation of this second text of creation. For it may lead some interpreters to assume as man was created first and the woman was also from the man's rib, therefore, the man is above the woman.

Although, one may accept the argument that there are two independent sources of the two stories, I would like to suggest as there are no substantial contradictions in these texts, then they should not be interpreted in isolation rather using a holistic approach for a better understanding. 'It should be noted that such duplications, although they may seem strange to those who are accustomed to the Hellenic process of thought, are not at all incongruous to the semitic way of thinking' (Cassuto 1989:90).

Indeed, it is true that God created human beings on an equal basis so that they might represent His glory on this earth. The creation of woman in the second position as we read in Genesis 2, does not put man above the woman.

The main goal in the creation of woman was to give the man a companion or helper (2:18). 'The woman was given to man as a companion so that they might be one, as it is expressed in the second chapter' (Calvin 1979:97). The term 'helper' sometimes means to complement. According to Hamilton (1990:179) 'Helper is actually part of himself. The woman as helper must with her nature and skills complete man'. Man cannot live without the companionship of woman. Bonhoeffer (1966:60-61) underlines the fact that:

Thus Adam knows that this creature, whom God has shaped with his assistance, out of his flesh, is unique, but he sees these actions of his upon the other entirely as a gift of God. The fact that Eve derives from him is in Adam's eyes not a cause for glorification but for special gratitude.

Being created in the image of God, the man and the woman should live in harmony and in a relationship that would create an atmosphere of wholeness. Throughout this life the man and woman have to live on an equal basis as the image of God. Clark (1980: 23) comments that: 
Complementarity implies an equality, a correspondence between men and women. The complementarity implies also a difference in that woman complements man in a way that makes her a helper to him. The role of the woman is not identical to the role of man. Their complementarity allows them to form a partnership in which each needs the other, because each provides something different from what the other provides. This partnership of man and woman is based upon a community of nature and an interdependence due to a complementarity of role. Life in partnership should not frustrate either one because love and respect should exist between them, an increase of common sharing on all levels of life.

God never intended to create man to be above the woman. The difference in their nature expresses the beauty that one can observe in the creation of God. His creation does not 'attribute strength to the man and weakness to the woman. Both the man and woman share the entire spectrum of human characteristic from strong to weak' (Hamilton 1990:181).

The fall of Adam and Eve in the third chapter of Genesis introduces another dimension in the understanding of the partnership between the man and the woman. Sin caused the 'desire to break the relationship of equality and turn it into a relationship of servitude and domination' (Hamilton 1990:202). 'What God intended to be a relationship of mutuality and companionship was characterized instead by domination' (Roop 1987:46). But does the curse of God on the woman to be subjected to man (Genesis 3:16) mean that man is the master and the woman the slave? I do not think that because of their fall God brought them in opposition to one another, and it does not mean as Delitzch 1978:106) underlines that: 'man commands as master and the woman is bound externally and internally to obey'. The subordination mentioned above should be taken in the dimension of love and compassion of God. In the New Dictionary of Theology (1988:258) one reads that:

Husband's role of headship (1 Cor 11:3; Eph 5:23) and the wife's role of submission are reaffirmed but radically altered. Submission becomes a mutual calling (Eph 5:21), transforming male headship from authoritative control to responsible care. Submission on the part of the wife is transformed from servility and subordination to respect (Eph 5:33). 
As the leader or head of the family, man is expected to exercise his position in such a away that his leadership would not mean absolute domination and oppression over the woman. Clark (1980:42) underlines this:

Genuine community cannot exist without unity-subordination. Many have attempted in recent years to form community without subordination. But if community is genuine, there must be subordination of people's lives to the greater unity and there must be some person or body which provides the order that makes that unity actual. Depending on the situation, such a subordination could lead to nothing but benefit for those who are subordinated. To be the head of the unity or community is not a simple task, it is a difficult one demanding self-sacrifice.

Man, as the head of the social unit (family) and the companion of woman, should create a climate that would respect her human rights. So, to maltreat her or to marginalise her would mean to deny God's creature. In the creation God did not distinguish between skills or roles but He gave them the same mission: 'Rule over the fish of the sea and the birds of the air and over every living creature that moves on the ground' (Genesis 1:28, NIV).

\subsection{The New Testament and Women}

The incarnation of God in the person of Jesus Christ and His presence in the midst of human beings shows the extent to which the new alliance of reconciliation and redemption from our sins was established between God and us ( $\operatorname{Rm~8:1-4;~} 2$ Cor 5:21). As a Saviour, Jesus Christ brought liberation to all people and to all races in the world. 'Our Lord Jesus Christ brings liberty to us. He sets us free from all kinds of manacles including tradition' (Tisani 1989:79).

As far as women are concerned, Jesus Christ's attitude about them was different from the rabbinic tradition. According to the rabbinic tradition, Clark (1980:240) comments that:

Women were restricted to the women's quarter of the home. They were not allowed to go out except for certain specified purposes and then their faces were to be fully veiled. Their duties consisted mainly of preparing meals, cleaning, bearing and feeding children, making beds and working with wool. 
Jesus Christ's teachings do not agree with the Talmud and the Midrash. He puts everybody on the same level. Women came to Him and He helped them personally. Clark (1980:240) underlines this fact that:

He heals them (Mk 5:25-34). He teaches them along with men (Lk 10: 38-42). He never shows disrespect to women, nor does he ever speak about women in disparaging way. He calls women daughters of Abraham (Lk 13:16), explicitly according them a spiritual status like that accorded to men.

Jesus Christ never taught against women. His love accepted all men and women as God's creatures. Therefore, there are no boundaries that should stop men and women working on an equal basis in society.

The problem in the New Testament regarding women exists in Paul's epistles. Paul taught about the attitude which should exist between men and women in the church of his time. And one has to bear in mind that Paul never made what he taught in Corinth on the issue of women to be a universal norm in all the churches that he had built. Paul was very specific, accurate and contextual in his missionary endeavour. I disagree with Knight (1975:222) when he declares that:

Paul laid down a universally normative regulation which prohibits women from teaching the church and from ruling and teaching the men in the church. The reason that the prohibition is universal is because it is grounded in God's creation order and arrangement between men and women.

It seems that Paul's teachings reflect the Jewish's attitude about women and are influenced by the teachings of the Talmud and the Midrash about the status of women. In the synagogue women were not counted to make up a quorum (Omoyajowo 1988: 77). Indeed, Paul was a Jew and he may have been influenced by his religious tradition, but at the same time it is not evident that it was so. What one needs to do is not to take Paul's teachings on women out of context. If one fails to understand what pushed Paul to teach in such a way, then any interpretation would always lead to conflict. I disagree with Tisani (1989:80) when he says that: 'For me that is one of the key explanations for the contradictions that abound in the Pauline letters'. There are no contradictions in Paul's letters. To avoid literal reading and interpretation of Paul's teachings 
regarding women (1 Cor 14:34; $1 \mathrm{Tm} 2: 11-12$ ), I suggest that Christians (especially theologians) should respect the relationships that exist between text and context. The lack of this factor only leads to confusion and also makes Paul appear to have little love and compassion for women.

\section{THE CHURCH AND FUTURE MISSIOLOGICAL PERSPECTIVES}

The church as God's agent for mission has the responsibility in fulfilling the salvation process in this world (Bassham 1979:23). "The mission of the church has its origin neither in the official church nor in special groups within the church. The church exists because there is a mission in which the church participates' (Bosch 1991:239). As God's agent, 'the church is responsible to its Lord to proclaim clearly and fearlessly the will of the living God' (Hromádka 1987:41).

The church is the body that acknowledges and confesses the headship of Jesus Christ (Bosch 1980:221-222). Therefore, it is the only voice that Jesus Christ uses in the world to side with the oppressed and bring a holistic salvation to people in the manner of Jesus Christ (Lk 4:18-19). It is in this way that the church has 'a particular vocation to proclaim this liberating story not only to its members but to the whole world' (Hromádka 1987:39). In being a participant liberating people from the power of sin, there is a great need to have a new biblical hermeneutic which would provide changes to the theology of the church in general so that all human beings would be accepted the way they are. In this regard, the human rights of women should be taken into consideration and be allowed to exercise any function in the church and society according to their abilities.

I believe that the feminist liberation theology which is a response by Christiar women to the oppression inherent in the patriarchal system of male domination which is found in most countries of the world' (Kritzinger 1992:251) is a true challenge to the Church worldwide which continues to further divide gender. In this regard it is sometimes difficult to condemn feminists while many churches still preach on the inferiority and subjection of women to men; the non-recognition of ordained female ministers as well as the limitation of the female roles in the church and society. Knight (1975:224) argues that:

Men and women manifest in their sexuality a difference created and ordered by God: Women by God's creative order are to be in subjection to men in the home and church, and are therefore excluded from the ruling and teaching offices (Eph 5:22; 1 Tm 2:11-15; 1 Cor 14:33b-37; 
1 Tm 3:4-5), which men are called on to fulfil in the diaconal task of the church, along with men, and in the teaching situations in relation to women and children (cf for example $1 \mathrm{Tm} 3: 11 ; 5: 9-10 \mathrm{ff}, \mathrm{Tt}$ 2:3-4; Rm 16:1).

The above interpretation does not show any spirit of equality, compassion or respect for women and of their ministry in the church. There are many churches which share the same understanding of Scripture as Knight does on the issue of women and their role in the church of Jesus Christ. This approach is not commensurate with the holistic salvation of God's creatures. 'The goal of salvation is comprehensive well-being in peace with God who is the source and criterion of the whole reality, and therefore also in peace with a pacified nature and human reality' (Nürnberger 1990:206).

The church should provide relevant missiological approaches, from which all its members would work in a way to bring salvation which would liberate people from all aspects of life. This transformation should help people to be real witnesses to others and influence the whole transformation of the society. 'Mission of the church should, therefore, not be judged by numbers alone but rather by how many individuals are influenced, who in turn will influence others' (Luzbetak 1988:328).

In liberating both men and women in society, the church would rise above the assumptions of the feminist liberation theology that expresses equality in terms of change of roles in the family. Women in the home would give less attention to mothering. For the sake of liberation and equality, a change of social status is needed (Hollis 1975:187). This is a challenge to the church to work for the well-being of a balanced society and where men and women should continue to participate in the process of God's creation on an equal basis. This equality would not mean that 'Women have abandoned certain feminine qualities, the traditional "savoir-faire" or that they have repudiated the past and started again from zero. It would simply mean that they no longer conform to the roles which men have assigned them' (Metz \& Schlick 1978:63).

Women have to discover their genuine rights and the church is their voice. The mission of the church cannot be fulfilled while it remains one of the agents of discrimination. 'Men and women should not indulge in recrimination for past injustices, but should move forward with the conviction that it is together that they make up the reality which is life' (Tisani 1989:83). As Clark (1980:IX) puts it that:

Most of what they should be doing is the same. But as we learn how to perceive and draw up the value of what is distinctive to men and to 
women, our lives together become stronger and more beautiful. There is something about women for which men cannot substitute, and vice versa.

Therefore, in midst of a culture where many are seeking liberation, Christians have good news to share. Jesus Christ brings true freedom and fulfilment to all people. This is the refreshing word that is breaking in upon our would. We are called to share the Good News that there is Christian freedom for women and men. In Christ we can all be free (Hollis 1975:189). The Word of God should be interpreted without assumptions and limitations of the skills based on gender. In everything there should be justice, peace, truth, compassion, reconciliation, healing, service and more - which are God's qualities and that should also be lived by all human beings created in His own image.

\section{End Notes}

1 The Evangelical Church of Zaire was built by the Swedish missionaries. Its works are mainly based among the Manianga people. They belong to the Bakongo ethnic group which lives in the western part of Zaire. In this regard, I would like to recommend readers to my doctoral thesis (Mulemfo 1995) for more information about the Church, the Manianga people and their context.

2 It is a small house in some of the wards of each village where only men have the privilege of gathering in the morning and in the evening and women are supposed to cook and bring food for men.

3 The expression 'local church' is used to indicate the church as the Christian Community (including all its congregations) which was planted by the Swedish missionaries.

4 The spiritual revival within the Christian Church in Lower Zair was experienced for the first time in the person of Simon Kimbangu. He was called 'ngunza' - prophet. He became a prophet in 1921 while he worked as a Protestant baptist evangelist in his own villiage. This spiritual revival influenced the lives of many people (for more information, cf Mulemfo 1995:130-133).

\section{Works Consulted}

Bassham, Rudger C 1979. Mission Theology: 1948-1975 years of Worldwide creative Tension Ecumenical, Evangelical, and Roman Catholic. Pasadena: William Carey Library.

Bonhoeffer, D 1966. Creation and Temptation. London: SCM Press.

Bosch, D J 1980. Witness to the world: The Christian Mission in Theological perspective. Atlanta: John Knox press. 
Bosch, D J 1991. Transforming Mission: Paradigm shifts in Theology of Mission. Maryknoll: Orbis Books.

Calvin, J 1979. Genesis. London: Billing \& Sons Ltd.

Cassuto, U 1972. A commentary on the Book of Genesis. Jerusalem: The Magnes Press.

Clark, S B 1980. Man and Woman in Christ: An examination of the Roles of Men and Women in the light of Scripture and Social sciences. Michigan: Servant Books.

Delitzch, F D P 1978. A New commentary on Genesis. Minneapolis: Klock Chris-tian Publishers.

Hamilton, V P 1990. The Book of Genesis: Chapters 1-17. Michigan: Eerdmans Publishing Co.

Hollis, H J et al 1975. Christian freedom for Women and other human beings. Nashville: Broadman Press.

Hromádka, J L 1987. Theology between Yesterday and Tomorrow. Philadelphia: The Westminster Press.

Knapen, M T 1962. L'enfant Mukungo. Louvain: éd. Nauvelaaerts.

Knight, G W 1975. New Testament teaching on the role relationship of male and female with special reference to the teaching-ruling functions in the Church. Journal of Psychology and Theology 3, 216-225.

Kritzinger, J N J 1992. The liberation model of mission, in Saayman, W A (ed), Introduction to Missiology 244-308. Pretoria: Unisa. (Only Study guide for MSA 100-3.)

Kukangisa, N 1988. Women's role in CEZ Evangelism, in Ingvar, H (ed), Mission Evangelisation, 122-126. Falköping: Gummessons Tryckeri AB.

Luzbetak, L J 1988. The Church and Cultures. Maryknoll: Orbis Books.

Maher, M 1982. Genesis. Delaware: Michael Glasier.

Metz, R \& Schlick, J 1978. Liberation Theology and the Message of Salvation. Pennsylvania: The Pickwick Press.

Mulemfo, M M 1995. Palaver as a dimension of communal solidarity in Zaïre: A missiological study on transgression and reconciliation. $\mathrm{Ph} \mathrm{D}$ thesis, University of Pretoria.

New Dictionary of Theology 1988. London: Inter-Varsity Press.

Nürnberger, K 1990. Salvation or liberation? The soteriological roots of a missionary theology. Missionalia 18/1, 205-219.

Omoyajowo, $J$ 1988. The role of Women in tradition African religious and independent Church movement. Dialogue and Alliance 2/3, 77-86. 
Palmaer, G \& Stenström, O 1961. Mavanga ma Nzambi mu kongo: Nsamu wa S.M.F. - M.E.S. 1881-1955. Matadi: Imprimerie de l'E.E.M.M.

Roop, E F 1987. Genesis. Ontario: Herald Press.

Stenström, O 1990. Mavanga ma Nzambi mu Kongo: Nsamu wa S.M.F. - M.E.S 1950-1961. Kinshasa: Cedi.

Tisani, N 1989. Christ the liberator: The attitude of the Church to the oppression of Women. Journal of Theology of Southern Africa 66, 79-85.

\section{Interviews}

Bikuta, T, Luozi, (Zaire) November 1993.

Luzolo, T, Sundi-Lutete, (Zaire) December 1993.

Massamba, K, Luozi, (Zaire) November 1993. 